\title{
AN ANALYSIS OF EXPERIENCES AND PROBLEMS FACED BY THE DENTISTS DURING COVID-19 PANDEMIC: A QUESTIONNAIRE-BASED SURVEY
}

\author{
HAFEEZ MM ${ }^{1 *}$, JAVED $Y^{2}$, HANIF $S^{3}$, HASEEB $M^{4}$, BUTT AF ${ }^{5}$, AFTAB $^{6}{ }^{6}$, RANA MA ${ }^{7}$ \\ ${ }^{1}$ Director Research and Development, Expert Doctor Private Limited, Lahore, Pakistan \\ ${ }^{2}$ Department of Oral pathology, CMH Lahore Medical and Dental College, Pakistan \\ ${ }^{3}$ Emergency Department, Bahria Town International Hospital Lahore-Pakistan \\ ${ }^{4}$ Department of Periodontology, University College of Medicine and Dentistry, The University of Lahore, \\ Lahore, Pakistan \\ ${ }^{5}$ Department of Physiology, University College of Medicine and Dentistry, The University of Lahore, \\ Lahore \\ ${ }^{6}$ Private Clinic, AR The Dental Studio, Lahore, Pakistan \\ ${ }^{7}$ Intensive Care Unit, Bahria International Hospital Lahore-Pakistan
}

Corresponding author email address: $\underline{\text { mansoorhafeez140@gmail.com }}$

(Received, $2^{\text {nd }}$ September 2021, Revised $29^{\text {th }}$ December 2021, Published $3^{\text {rd }}$ January 2022)

\begin{abstract}
Severe Acute Respiratory Syndrome Coronavirus-2 pandemic started in December and spread around the globe in a few months. Nosocomial transmission of this virus shut down the dental clinics and creates many problems for patients. This study was designed to assess the experiences and problems faced by the dentist during the pandemic. The was a cross sectional questionnaire-based survey conducted in different dental sectors of Lahore. The questionnaire was distributed through online Microsoft form and total of seventy-eight complete responses were received out of 156 dentists contacted. $69.2 \%$ of participants reported that they stop taking appointments during the peaks of pandemic or have planned to stay at home till the end of the pandemic where $27 \%$ claimed to perform only emergency procedures. $86 \%$ of dentists reported having difficulty finding PPE and $97 \%$ had to buy it at a much higher cost. Dentists (96\%) also reported that they are facing a significant decrease in income and needed some other source of income. Regarding financial issues they did not get any government support. The COVID-19 pandemic has a significant impact on dentistry. Most dental clinics remained closed, placing a financial burden on the dental profession. This burden was further increased as a result of the scarcity and high cost of PPE. There is a need for standardized protocols to prevent the spread of infection, and government agencies should also consider private clinics for funding and provision of low-cost PPE.
\end{abstract}

Keywords: SARS-CoV-2, Dental Practice, Personal Protective Equipment, Dentist Experiences, coronavirus

\section{Introduction}

A unique coronavirus illness 2019 (COVID-19) outbreak appeared in Wuhan, China, in December. This virus rapidly spread around the globe and disturbed all the fields of life. SARS-CoV-2 (Severe Acute Respiratory Syndrome Coronavirus-2) has similar symptoms to SARS-CoV-1 (Singhal, 2020). Symptoms include fever, dry cough and tiredness, are similar in both pandemics but SARS-CoV2 transmission rate is much faster. It can spread through respiratory droplets and contaminated surfaces, mucous membranes in the mouth, nose, and through the fecal oral route (Lu et al., 2020). Due to the extremely transmissible nature of the virus, several medical establishments have decided to suspend all elective operations to lower the risk. During dental operations, the use of hand gadgets, and ultrasound devices inevitably lead to the formation of blood droplets and the saliva (Bizzoca et al., 2020). Therefore, these dental tools and the office environment could be contaminated by droplets. This can put dentist and patients at risk for microbial contaminations. In this context, the investigators recommended that dental hospitals could be a potential source of virus transmission, like hepatitis and human immunodeficiency virus. So, there is an elevated risk of transmission during the dental procedure to both patients and dentists (Ciesielski et al., 1992). The highly infectious nature of SARS$\mathrm{CoV} 2$, as well as the fact that dental surgery often creates droplets of blood and saliva, allowing the

[Citation: Hafeez, M.M., Javed, Y., Hanif, S., Haseeb, M., Butt, A.F., Aftab, A., Rana, M.A. (2022). An analysis of experiences and problems faced by the dentists during COVID-19 pandemic: A questionnaire-based survey. Biol. Clin. Sci. Res. J., 2022: 89. doi: https://doi.org/10.54112/bcsrj.v2022i1.89] 
virus to spread. This prompted the American Dental Association (ADA) to recommend that dentists should do only emergency interventions. In addition, to minimize the risk of infection during the pandemic, some precautions need to be taken(Kirkpatrick et al., 2020). For example, providing patients with a preprocessing mouth wash on a regular basis and cleaning dental tools on a regular basis. In addition, large volume saliva ejectors, non-retracting Handpieces, rubber barrier insulation and personal protective equipment (PPE) should be used to minimize the risk of transmission. Dental treatments for patients have been impacted by the closure of dental clinics as a result of the COVID19 outbreak (Ahmed et al., 2020). Furthermore, it has been suggested that dentists may be a potential source of virus, transmission of their get asymptomatic infection. Therefore, in the first few days of the outbreak, dental care was limited to emergency situations(Chang et al., 2021). The goal of this study was to assess the influence of the COVID19 epidemic on dental practice in Lahore. This included the online survey based on specific questions for the assessment of dentists' experience and problems during the pandemic.

\section{Methodology}

This is a cross sectional analysis conducted from September 21 st to October 10, 2021. An online questionnaire form was distributed to the dentists of private clinics, hospitals, and non-profitable organizations of Lahore. The questionnaire was designed by the specialist and consultants working in CMH hospital Lahore. A total of seventy-eight respondents were included in the study who completed the survey form. The first section of questionnaires including the demographic variable of the respondents and the second section multiple choice question assessing the experiences and problems encountered by the dentist during the covid-19 pandemic. The study was approved by the ethical review board of the institute. The questionnaire was distributed online by using the Microsoft form. A trained person with no knowledge of the names and degrees of the participants collected the results. A group of three experience persons of the research group examined the retrieved data for accuracy. Descriptive state was used to analyze the items in the study. Data was collected and analysis with the help of SPSS software version 25 .

\section{Results}

The response rate of the study was $58.3 \%$ as a total of 156 dentists were contacted and received 91 response forms, out of which thirteen forms were incomplete, so we left with a total of seventy-eight response form. Male to female ratio was 48:30, respectively. Most of the participants belonged to the age group of 24-35 yeas (37.2\%). $36(43.6 \%)$ of dentists had the experience from 6 to 10 years. $75.6 \%$ of respondents were married and $57(72.15 \%)$ having children. Departments and sector of practice also mentioned in table 1.

Table 1 The demographic data of the dental practitioners $(\mathrm{N}=78)$

\begin{tabular}{llll}
\hline Variables & constructs & Frequency (n) & Percentage (\%) \\
\hline Age (years) & $24-35$ & 29 & 37.2 \\
& $36-45$ & 20 & 25.6 \\
& $46-55$ & 18 & 23.1 \\
Years of experience & $>56$ & 11 & 14.1 \\
& $2-5$ & 23 & 29.5 \\
Gender & $6-10$ & 36 & 46.2 \\
& $>10$ & 19 & 24.4 \\
Marital status & Male & 48 & 61.5 \\
& Female & 30 & 38.5 \\
Number of children & Single & 19 & 24.4 \\
& Married & 59 & 75.6 \\
& 1 & 10 & 12.8 \\
Field of practice & 2 & 15 & 19.2 \\
\hline
\end{tabular}

[Citation: Hafeez, M.M., Javed, Y., Hanif, S., Haseeb, M., Butt, A.F., Aftab, A., Rana, M.A. (2022). An analysis of experiences and problems faced by the dentists during COVID-19 pandemic: A questionnaire-based survey. Biol. Clin. Sci. Res. J., 2022: 89. doi: https://doi.org/10.54112/bcsrj.v2022i1.89] 


\begin{tabular}{llll}
\hline & Prosthodontics & 11 & 14.1 \\
& Orthodontics & 23.0 & 14.1 \\
& Oral/Maxillofacial Radiology & 11 & 10.3 \\
Oral/Maxillofacial Surgery & 8 & 7.7 & 9.0 \\
Endodontic & 6 & 9.0 & 41.0 \\
Operative dentistry & 7 & 32.1 \\
Gealth sector & Private sector & 32 & 26.9 \\
\hline
\end{tabular}

Table 2 shows the attitude and experiences of the dentist during the covid-19. 43.6 percent of the dentist closed their clinics or have plans to cancel all appointments during the peaks of COVID-19 pandemic while 27 percent dentist agreed to perform the only emergency procedure and restorative treatment for dental carries found to be the most common emergency procedure (29.5\%). Most dentists devote their spare time to reading and communicating online with co-workers and patients. Mixed responses were seen in finding the PPEs. More than fifty percent respondent faced difficulty in finding the PPE. The policy to open dental clinics over which most dentists agreed was to treat patients with the negative RT-PCR report.

Table 2 Experiences and attitude of dentist during COVID-19 pandemic $(\mathrm{N}=78)$

\begin{tabular}{|c|c|c|c|}
\hline Variables & constructs & Frequency (n) & Percentage $(\%)$ \\
\hline \multirow{4}{*}{$\begin{array}{l}\text { Any change in the treatment plan of } \\
\text { pandemic }\end{array}$} & No at all & 3 & 3.8 \\
\hline & $\begin{array}{l}\text { Plan to cancel all treatment till the } \\
\text { end of pandemic }\end{array}$ & 20 & 25.6 \\
\hline & $\begin{array}{l}\text { Plan to cancel appointment during the } \\
\text { peaks }\end{array}$ & 34 & 43.6 \\
\hline & Plan for emergency treatment only & 21 & 27 \\
\hline \multirow[t]{5}{*}{$\begin{array}{l}\text { Emergency procedure should be done } \\
\text { during COVID-19 pandemic. }\end{array}$} & $\begin{array}{l}\text { No non-emergency procedure should } \\
\text { be performed }\end{array}$ & 5 & 6.41 \\
\hline & Only aesthetic procedures & 14 & 17.9 \\
\hline & Restorative treatment & 23 & 29.5 \\
\hline & Extraction of teeth & 15 & 19.2 \\
\hline & General routine examination & 21 & 26.99 \\
\hline \multirow[t]{3}{*}{ Revival of normal clinical working Hours } & Till the end of Pandemic & 22 & 28.2 \\
\hline & Till the end of the peak phase & 33 & 42.3 \\
\hline & The clinic should remain open & 23 & 29.5 \\
\hline \multirow[t]{4}{*}{$\begin{array}{l}\text { Strategy for the reopening of dental } \\
\text { clinics }\end{array}$} & $\begin{array}{l}\text { Don't have any plan to open till the } \\
\text { end of COVID- } 19 \text { pandemic }\end{array}$ & 9 & 11.6 \\
\hline & $\begin{array}{l}\text { Attend patients having COVID-19RT- } \\
\text { PCR report negative. }\end{array}$ & 30 & 38.4 \\
\hline & Attend only asymptomatic patients & 14 & 17.9 \\
\hline & Attend patient $s$ without PPE & 25 & 32.1 \\
\hline \multirow[t]{5}{*}{ How do you fill your free time? } & no free time & 12 & 15.3 \\
\hline & Spent time in research & 14 & 17.3 \\
\hline & Communicate online with others & 22 & 27.2 \\
\hline & Spend free time in study & 21 & 29.1 \\
\hline & Mostly do exercise & 9 & 11.1 \\
\hline \multirow{2}{*}{$\begin{array}{l}\text { Did you find difficult to find the any of } \\
\text { the? }\end{array}$} & Problem in finding PPE & 41 & 52.5 \\
\hline & Difficult to find Dis infectant solutions & 37 & 47.5 \\
\hline
\end{tabular}

[Citation: Hafeez, M.M., Javed, Y., Hanif, S., Haseeb, M., Butt, A.F., Aftab, A., Rana, M.A. (2022). An analysis of experiences and problems faced by the dentists during COVID-19 pandemic: A questionnaire-based survey. Biol. Clin. Sci. Res. J., 2022: 89. doi: https://doi.org/10.54112/bcsrj.v2022i1.89] 
Most dentists facing difficulty in finding PPE ( $\mathrm{n}=$ $67,86 \%$ ) during the peaks of pandemics. Approximately all participants indicated that they had to buy PPE at a much higher cost (97\%). 96\% of participants said they have confronted a decline in their income since the start of the pandemic. While only 3 percent of them got financial aid from government agencies. Over onethird of respondents claimed they need some other source of income to run their routine household matters. $54 \%$ of dentists had to pay their Co works even when the clinics were closed, and $24 \%$ of dentists indicated that they had notified them to get income for their daily household work from other sources. The chi square test did not reveal any association between the reduced income with experiences and other factors like marital status ( $P$ value $>0.05)$. Similarly, we found no significant link between PPE use and dental work experience (P value $>0.05)$. (Table 3 )

Table 3 the problems faced by the Dentist during COVID-19 Pandemic

\begin{tabular}{|c|c|c|c|c|}
\hline \multirow{2}{*}{$\begin{array}{l}\text { Problems you find during the COVID- } \\
19 \text { pandemic? }\end{array}$} & \multicolumn{2}{|c|}{ Yes } & \multicolumn{2}{|c|}{ No } \\
\hline & Frequency (n) & Percentage (\%) & Frequency(n) & Percentage $(\%)$ \\
\hline Availability of PPE & 67 & 86 & 11 & 14 \\
\hline Increasing prices of PPE & 76 & 97 & 2 & 3 \\
\hline $\begin{array}{l}\text { Did you receive any help from public } \\
\text { sector in provision of PPE }\end{array}$ & 9 & 12 & 69 & 88 \\
\hline The usage of PPE has increased & 76 & 97 & 2 & 3 \\
\hline Decrease of income & 75 & 96 & 3 & 4 \\
\hline $\begin{array}{l}\text { Received any financial support from } \\
\text { non-profitable organizations }\end{array}$ & 2 & 3 & 76 & 97 \\
\hline $\begin{array}{l}\text { Do you have any other source of } \\
\text { income except dental procedures }\end{array}$ & 30 & 38 & 48 & 62 \\
\hline $\begin{array}{l}\text { Feel of financial problems on future } \\
\text { also }\end{array}$ & 45 & 58 & 33 & 42 \\
\hline $\begin{array}{l}\text { Downsize the staff due to financial } \\
\text { problems }\end{array}$ & 34 & 44 & 44 & 56 \\
\hline $\begin{array}{l}\text { Did your co-workers refused to work } \\
\text { during pandemic? }\end{array}$ & 33 & 42 & 45 & 58 \\
\hline $\begin{array}{l}\text { I had to pay the assistants, regardless } \\
\text { of the closing of the dental clinics. }\end{array}$ & 42 & 54 & 36 & 46 \\
\hline $\begin{array}{l}\text { Recommended your assistants to find } \\
\text { some other way of earning }\end{array}$ & 19 & 24 & 59 & 76 \\
\hline
\end{tabular}

Discussion

Air droplet transmission of SARS-CoV-2 is of concern to dentists as it is a potential source of infection transmission for both dentists and the patients (Volgenant et al., 2021). Literature survey showed that the asymptomatic infected doctors can be the greatest source of COVID-19 virus spread. Some participants said the reopening of clinics for non-emergency dental procedure could escalate the number of COVID-19 cases, so in their opinion the dental clinics should remain closed during the pandemics (Mariner, 2021). Thus, during the pandemic, the dentist encourages the maintenance of good dental hygiene to avoid unnecessary visits to the dental clinic for the general population. Our data showed that most of the dental clinics perform mostly low risk emergency dental procedures. These procedures include simple tooth extraction for dental carries. Keeping the emergency procedure in view, it can the postulated that there is a chance of increase in demand of removable prosthetic in the future during the peaks of pandemics. However, as the epidemic progressed, it was suggested that the dental community could also provide elective treatments. According to a study led by the ADA Health Policy Institute, more than ninety percent of dental clinics now offer elective care facilities. Center for disease

[Citation: Hafeez, M.M., Javed, Y., Hanif, S., Haseeb, M., Butt, A.F., Aftab, A., Rana, M.A. (2022). An analysis of experiences and problems faced by the dentists during COVID-19 pandemic: A questionnaire-based survey. Biol. Clin. Sci. Res. J., 2022: 89. doi: https://doi.org/10.54112/bcsrj.v2022i1.89] 
control (CDC) has developed guidelines to prevent the spread of infection(Jamal et al., 2021). Every dental clinic must follow these guidelines during elective procedures. The guidelines included the proper use of personal protective equipment (PPE), like as gowns, gloves, face shields, goggles, and face masks. Application of these guidelines is critical in avoiding the spread of the virus from healthcare professionals to patients and vice versa. Whereas the significant increase in demand for PPE has led to a global shortage of supplies. Most of the participants in this research claimed that their PPE usage had increased dramatically, and that more than fifty percent of them had difficulty in acquiring face masks. Literature also showed that the cost of PPE has gone up significantly, which could indicate a shortage. Increased expenditures on PPE may also contribute to increased expenditures on dental care(Brian and Weintraub, 2020). Government agencies, on the other hand, did not help practitioners to obtain this equipment as claimed by many studies including our survey. A considerable percentage of dental practitioners were experiencing financial difficulties due to their reduced work schedule and dental operations are prohibited during the pandemic. Research has constantly disclosed that the COVID-19 epidemic has caused financial hardship to dental practitioners (Ahmadi et al., 2020). Over half of dentists working in Lahore used their savings to cover their daily expenditures. Yet a small number of them have been funded by government agencies. These results suggest that the concerned organizations should step up their endeavors to support dentists in these challenging times(Albert et al., 2002). If dental employee support payments are not paid, the number of workers facing financial hardship will increase as the COVID-19 outbreak continues. In addition, almost half of those who participated in our research showed signs of hopelessness and anxiety. During the COVID-19 outbreak, it was reported that health care workers experienced significantly higher emotional stress than the general population (Vizheh et al., 2020). During pandemics, increased workload, work with changing procedures, PPE, social distancing, self-isolation, and worsening patient care are the most prevalent concerns among health care professionals. As well, resources are scarce during pandemics, making tough decisions for employees.

\section{Conclusion}

Most dentists preferred to reduce their hours of work and suggested to restrict dental practices to emergency procedures only until the end of or at least during the peaks of pandemics. They also believe that the complete reopening of dental hospital for all kind of procedure could result in increased transmission of SARS-CoV-2. In addition, dentists have had financial difficulties because of the shutting down of dental clinics that can led to psychological trauma. We recommend on the basis of current analysis on dentist experiences and problems that governmental organizations must take necessary action to resolve the financial crisis in these unusual times. Researchers should also look at the impact of COVID-19 on dental practice and try to find out the solutions of upcoming problems.

\section{Limitations}

Descriptive analysis and sampling technique (online questionnaire distribution) was the limitation of the study.

\section{Conflict of interest}

Authors declare no conflict of interest

Funding

This survey is not funded by any third party

\section{References}

Ahmadi, H., Ebrahimi, A., and Ghorbani, F. (2020). The impact of COVID-19 pandemic on dental practice in Iran: A questionnaire-based report. BMC oral health 20, 1-9.

Ahmed, M. A., Jouhar, R., Ahmed, N., Adnan, S., Aftab, M., Zafar, M. S., and Khurshid, Z. (2020). Fear and practice modifications among dentists to combat novel coronavirus disease (COVID-19) outbreak. International journal of environmental research and public health17, 2821.

Albert, D., Ward, A., Ahluwalia, K., and Sadowsky, D. (2002). Addressing tobacco in managed care: a survey of dentists' knowledge, attitudes, and behaviors. American Journal of Public Health92, 997-1001.

Bizzoca, M. E., Campisi, G., and Lo Muzio, L. (2020). Covid-19 pandemic: What changes for dentists and oral medicine experts? A narrative review and novel approaches to infection containment. International journal of

[Citation: Hafeez, M.M., Javed, Y., Hanif, S., Haseeb, M., Butt, A.F., Aftab, A., Rana, M.A. (2022). An analysis of experiences and problems faced by the dentists during COVID-19 pandemic: A questionnaire-based survey. Biol. Clin. Sci. Res. J., 2022: 89. doi: https://doi.org/10.54112/bcsrj.v2022i1.89] 
environmental research and public health17, 3793.

Brian, Z., and Weintraub, J. A. (2020). Peer Reviewed: Oral Health and COVID-19: Increasing the Need for Prevention and Access. Preventing chronic disease 17.

Chang, T.-Y., Hsu, M.-L., Kwon, J.-S., Kusdhany, M. L. S., and Hong, G. (2021). Effect of online learning for dental education in asia during the pandemic of COVID-19. Journal of Dental Sciences 16, 1095-1101.

Ciesielski, C., Marianos, D., Ou, C.-Y., Dumbaugh, R., Witte, J., Berkelman, R., Gooch, B., Myers, G., Luo, C.-C., and Schochetman, G. (1992). Transmission of human immunodeficiency virus in a dental practice. Annals of Internal Medicine116, 798-805.

Jamal, M., Shah, M., Almarzooqi, S. H., Aber, H., Khawaja, S., El Abed, R., Alkhatib, Z., and Samaranayake, L. P. (2021). Overview of transnational recommendations for COVID-19 transmission control in dental care settings. Oral diseases 27, 655-664.

Kirkpatrick, J. N., Mitchell, C., Taub, C., Kort, S., Hung, J., and Swaminathan, M. (2020). ASE statement on protection of patients and echocardiography service providers during the 2019 novel coronavirus outbreak: endorsed by the American College of Cardiology. Journal of the American College of Cardiology75, 30783084.

Lu, C.-w., Liu, X.-f., and Jia, Z.-f. (2020). 2019$\mathrm{nCoV}$ transmission through the ocular surface must not be ignored. Lancet (London, England)395, e39.

Mariner, W. K. (2021). Shifting Standards of Judicial Review During the Coronavirus Pandemic in the United States. German Law Journal22, 1039-1059.

Singhal, T. (2020). A review of coronavirus disease2019 (COVID-19). The indian journal of pediatrics87, 281-286.

Vizheh, M., Qorbani, M., Arzaghi, S. M., Muhidin, S., Javanmard, Z., and Esmaeili, M. (2020). The mental health of healthcare workers in the COVID-19 pandemic: A systematic review. Journal of Diabetes \& Metabolic Disorders, 112.

Volgenant, C. M., Persoon, I. F., de Ruijter, R. A., and de Soet, J. (2021). Infection control in dental health care during and after the SARS-CoV-2 outbreak. Oral diseases 27, 674683.

\section{(c) (i) (8)}

Open Access This article is licensed under a Creative Commons Attribution 4.0 International License, which permits use, sharing, adaptation, distribution and reproduction in any medium or format, as long as you give appropriate credit to the original author(s) and the source, provide a link to the Creative Commons licence, and indicate if changes were made. The images or other third party material in this article are included in the article's Creative Commons licence, unless indicated otherwise in a credit line to the material. If material is not included in the article's Creative Commons licence and your intended use is not permitted by statutory regulation or exceeds the permitted use, you will need to obtain permission directly from the copyright holder. To view a copy of this licence, visit http://creativecommons.org/licenses/by/4.0/.

(C) The Author(s) 2022
[Citation: Hafeez, M.M., Javed, Y., Hanif, S., Haseeb, M., Butt, A.F., Aftab, A., Rana, M.A. (2022). An analysis of experiences and problems faced by the dentists during COVID-19 pandemic: A questionnaire-based survey. Biol. Clin. Sci. Res. J., 2022: 89. doi: https://doi.org/10.54112/bcsrj.v2022i1.89] 